\title{
EDITORIAL
}

\section{O CÓDIGO BEM RECEBIDO}

Entra o novo ano 1980. Que progresso teremos na profissão, em seu crescimento expresso na qualidade do serviço prestado? Espera-se, até dezembro de 1980, um aumento encorajador do número de graduados em enfermagem e obstetricla. Conta-se também com o oferecimento de empregos em nivel razoável, uma vez que está crescendo a assistência à saúde dos trabalhadores, isto é, dos que descontam para a Previdência e Alssistência Social.

Quanto à melhora gradual dos serviços de assistência à saúde, sem dúvida é o que almejamos. De que dependerá essa melhora? Podemos responder mencionando suprimento de material e aumento de recursos humanos. $t$ verdade. Mas há um terceiro fator e esse seria melhora da qualidade de nosso trabalho profissional.

Uma ilustração nos ajudará a ver o ponto. Tentaremos o paralelo de uma estória.

Um engenheiro e sua familia moraram muitos anos numa cidadezinha, enquanto ele se responsabilizava por uma grande obra de engerharia; fora tão prolongada e importante que o ocupara por muitos anos. Nasceram-lhe ali quatro de seus filhos.

Um dia chegou-1he a designação que já esperava, para um empreendimento em outra cidade. Para arrrumar a mudança, o casal ocupourse, concentrado, de muitos deliberações. Estudado o espaço na casa da nova sede, tomou-se tempo para grupar os objetos: uns, preciosos ou úteis foram embalados para a mudança; outros, foram dados a familias que deles necessitavam; alguma coisa foi posta fora.

A vida profissional, no começo deste novo periodo, é comparável a uma mudança. Refletidamente, vamos decidir o que queremos que fique conosco e o que precisa ser deixado para trás. 
O que é inseparável de um profissional, aquilo que é próprio dos que traba!ham bem, deve ficar conosco. Aqueles erros que vamós acumulando durante anos devem ser deixados atrás. Hábitos bons, caráter, verdade na comunicação, senso de responsabilidade vão ser levados. Queremos o que nos constrói, como pessoa e como profissional. Deixamos o que afinal nos destrói. Relegamos para trás atitudes negativas, malícia, comentários prejudiciais a outrem, desídia, falta de esforço para aprender, desânimo, saúde abalada por tais atitudes indesejáveis.

Ao começarmos o ano, pensemos cuidadosamente nessas prioridades mencionadas. As estratégias que cada um de nós escolherá deve ser de decisão pessoal. A força que nos impulsionará é Deus. Em termos laicos, são os nossos valores. Estes, para cada um, valem $A$ sintese de nossos valores na enfermagem acha-se, à maneira de decálogo, no Código que o Conselho Fede ral de Enfermagem aprovou para a norma de deontologia da classe. Digamos como o salmista: "Por meio dos teus preceitos consigo entendimento" e também: "Os preceitos do Senhor alegram o coração. . e são mais doces do que o me! e o destilar dos favas". (H.G.D.) 